\title{
农村污水处理设施运行维护管理建议
}

范思禹

北京市密云区水务局

DOI:10.32629/hwr.v3i5.2156

[摘 要] 北京市密云区农村污水处理设施除部分新建设施外,多数设施建设投运时间久远,设备陈旧,日常运行维护时存在较 多问题且情况复杂, 需专业运行维护单位负责。但目前农村污水处理设施运行维护单位存在着一些问题, 本文针对这些问题进 行分析与建议。

[关键词]农村污水处理; 运维管理; 建议

引言

按照《北京市加快污水处理和再生水利用设施建设三年 行动方案 (2016. 7-2019.6)》和《实施乡村振兴战略扎实推进 美丽乡村建设专项行动计划 (2018-2020 年)》的有关要求, 采 用 “城带村”、“镇带村”、“联村”、“单村” 等模式, 集中或分 散建设污水处理设施; 人口较少的村庄要因地制宜, 通过湿地 等多种方式进行污水处理 ${ }^{[1]}$ 实现城乡结合部地区、重要水源地 和民俗村庄基本实现污水处理设施全覆盖的目标 ${ }^{[2]}$, 届时北京 市绝大多数, 均建有污水收集、处理设施, 为保证设施发挥应 有的效益, 设施的运行管理工作将成为重中之重。

\section{1 农村污水处理设施运行维护现状}

以北京市密云区为例, 现有农村污水处理设施主要通过 《新农村五项基础设施建设》、《市级新农村试点村污水治理工 程》、《新农村五项基础设施建设》、《小流域治理工程》和搬迁 村配套工程或村集体自主建设等方式完工。除少部分设施外, 多数农村污水处理设施建设年度久远, 设备陈旧, 日常运行维 护时存在较多问题且情况复杂, 需专业运行维护单位负责。但 目前农村污水处理设施运行维护单位依然存在着一些问题。

\begin{tabular}{|c|c|c|}
\hline \multicolumn{3}{|c|}{ 表 1 北京市密云区农村污水治理项目实施年度 } \\
\hline 序号 & 项目名称 & 实施年度 \\
\hline 1 & 市级新农村试点村污水治理工程 & 2006 \\
\hline 2 & 新农村污水治理工程 & 2008 \\
\hline 3 & 新农村五项基础设施建设 & $2009-2010$ \\
\hline 4 & 其他 & - \\
\hline 注: 小流域及搬迁村配套工程等, 依照主体工程实施年度, 同年实施 \\
\hline
\end{tabular}

\section{2 农村污水处理设施运行维护存在的问题}

2.1 日常维护工作不负责

受地理条件约束, 农村污水处理设施一般较为分散, 路 程较远, 日常维护班组需配备车辆 (司机) 与水电工、机修人 员和安全员等必须人员。极少数运行维护单位为节约运行成 本, 降低开支, 人员配备严重不足, 日常维护班组存在水、电 工、机修人员和司机一身兼, 同时缺乏安全防护措施, 且维护 中心距农村污水处理设施站点路程较远, 很难及时到达现场。

\section{2 “重建轻管” 情况依然存在}

北京地区因政策要求农村污水处理设施建设均在一定 时间内必须完工, 同一时间内开工处数多, 建设工程量大, 人
员及资料投入极大。但在后期运行维护时, 由于山区所建农 村污水处理设施规模较小, 设施布局又比较分散, 给运行维 护工作造成了较大的困难, 增加了运行成本 ${ }^{[3]}$ 。如果运维单 位疏于管理或管理松解, 人员配置不足、日常工作量大, 导致 巡查工作不到位, 不能及时发现问题, 并进行处理, 影响农村 污水处理设施运行。

\section{3 轻视污水收集工作}

污水处理设施管网为农村污水治理的基本, 如果污水收 集管网不能正常运行, 处理厂站将闲置, 发生 “无水可转” 的 现象。农村污水收集管网如果 “只建缺管” 或 “只建不管”, 那么污水处理设施运行数年, 收集管网无人清理疏通, 最终 完全淤堵, 污水处理站无水可进、无水处理, 污水自淤堵点外 溢, 污染环境。为使污水再次得到治理, 只得翻工新建收集管 网, 造成资金浪费。

\section{3 建议及意见}

农村污水处理设施的建设与管理, 重点应该放在运行管 理, 建设只是一时之功, 而长久、稳定的运行则是重中之重、 核心工作, 否则大量的建设资金只是一时的浪费, 不能发挥 长久的效益。个人认为做好运行管理工作应做到以下几点:

3.1 运维单位的内部管理与相应设置

运维单位加强自身建设。运维单位作为农村污水处理设 施日常维护的一线单位, 一定要注意本单位的自身建设和日 常管理工作。

3.1.1运维小组作为农村污水处理设施日常运行维护的 基本单位, 需要配备司机、水电工、机修等人员, 为保证作业 安全及工作效率, 最少应为 3 人一座, 1 名司机、 2 名机修, 确保 日常作业时有人进行看护及备勤。

3.1 .2 为节约路程时间, 及时处置突发事件, 在维护路程 较为偏远, 分布面积较大的农村污水处理设施时, 还应设置运 维分中心和货储仓库, 并储存常用设备, 以便突发应急事件时, 进行及时处置, 同时还可以节约路程时间, 增加工作效率。建 议运维中心和货储仓库覆盖面积在半小时路程圈内, 即从运 维中心出发半小时内可到达最远农村污水处理设施站点。

3.1 .3 运维单位应在日常维护中注意经常发生的问题, 尽快报知业主单位, 并向业主单位提出提升改造建议。同时 
应定期组织安全演习, 应急处置工作培训以及员工的职业培 训工作, 提高运维人员职业素质与技能。

\section{2 调整资金、人力投入比例}

3.2.1 杜绝 “重建设、轻管理”、摒弃 “重厂站、轻管网”。 农村污水处理工作的成果不是简单的处理站和收集管网的建 设工作, 而是日后处理设施长久稳定运行, 出水达标排放。应 将大量资金和人力投入到农村污水处理设施日常运行维护工 作中, 以确保前期投入的大量建设资金发挥应有效益。防止污 水处理厂站建设完工后厂站无水可处理, 设备搁置废弃。

3.2 .2 增大农村污水处理设施后期维护及补助力度, 改 变补助方式。目前北京地区农村污水收集管网建设中, 按照 生态涵养区 $90 \%$ 比例, 朝阳区、海淀区、丰台区 $50 \%$ 比例, 其 他区 $70 \%$ 比例对污水收集骨干管网予以资金支持 ${ }^{[4]}$ 。市财政 部门对农村污水处理和再生水利用设施运营经费给予补贴, 补贴基数为 3 元/立方米, 补贴比例生态涵养区为 $70 \%$, 城市 发展新区为 $60 \%$, 城市功能拓展区为 $50 \%$, 不足部分由各区财 政部门统筹解决 ${ }^{[5]}$ 。但村级污水处理设施相对分散, 规模小, 计量管理成本高 ${ }^{[6]}$ 。如果农村污水处理站建成后受运行费限 制, 导致不能稳定运行, 那么大笔补贴建设资金将出现浪费。 建议将建设补贴资金分为数年结合运行补贴资金每年按照 农村污水处理设施运行情况进行补贴, 待农村污水处理设施 严重损坏或到大修年限后, 经专家论证后予以重建或大修。 以农村污水处理设施的运行补贴资金督促前期工程质量把 控及后期管理维护水平。

\begin{tabular}{|c|c|c|}
\hline \multicolumn{3}{|c|}{ 表 2 北京地区农村污水收集管网建设补助比例 } \\
\hline 序号 & 区域 & 补助比例 $/ \%$ \\
\hline 1 & 生态涵养区 & 90 \\
\hline 2 & 朝阳区、海淀区、丰台区 & 50 \\
\hline 3 & 其他区 & 70 \\
\hline
\end{tabular}

3.2. 3 加强运行维护力度, 全面维护污水收集系统。由 于农村三格化粪池缺少定期清理, 导致化粪池内氨氮超标, 甚至固体废弃物进入管网, 造成污水收集管网淤堵, 处理厂 站水质不稳定, 维护成本增加。日常运行维护工作中, 应注意 定期维护污水收集前端, 即三格化粪池等设施。

3.3 严格审批, 制定新标准

严格审核专业化运营单位, 使运维管理能力不高或缺乏 运维管理能力的运营单位转型或退出市场。建议出台相应运 维标准, 强制定期对全部收集管网进行疏通、清淤, 延长污水 收集管网使用寿命。

\section{4 结语}

农村污水处理设施运行维护管理工作是一项漫长而艰 难的工作, 并非一日之功, 也不能一蹴而就。有关部门应在提 高农村污水处理设施覆盖范围的同时, 重视设施的运行维护 管理工作, 确保国家资金发挥应有效益, 污水得到有效治理, 保护我们宝贵的水资源。

\section{[参考文献]}

[1]实施乡村振兴战略扎实推进美丽乡村建设专项行动 计划(2018-2020 年)[N].北京日报,2018-02-09(004).

[2]推进生态文明建设美丽北京[N].中国水利报,2013-05-23(4).

[3]高晓兰, 郭一令.常熟市农村生活污水处理设施的调 查研究 [J].农村经济与科技,2013,24(4):14-15.

[4]魏改霞,吴连成,刘峻,等.中原地区农村污水处理工程 设计与运行[J].工业水处理,2018,38(11):93-95.

[5]谢林花,吴德礼,张亚雷.中国农村生活污水处理技术现 状分析及评价[J].生态与农村环境学报,2018,34(10):865-870.

[6]汪元元,王凤春,马东春.北京市城乡结合部污水处理设 施运行管理模式[J].南水北调与水利科技,2011,09(5):136-140. 